\title{
Microscopic Examination of Placenta of Rats Prenatally Exposed to Aloe barbadensis: A Preliminary Study
}

\author{
Examen Microscópico de la Placenta de Ratas Prenatalmente Expuestas a Aloe barbadensis: Estudio Preliminar
}

\author{
*Rengin Kosif; *Gülhan Akta \& **Aynure Öztekin
}

KOSIF, R.; AKTA, G. \& ÖZTEKIN, A. Microscopic examination of placenta of rats prenatally exposed to Aloe barbadensis: A preliminary study. Int. J. Morphol., 26(2):275-281, 2008.

SUMMARY: Aloe barbadensis is the most widely used both commercially and therapeutic properties. It has been used for an array of ailments since ancient times as a medicinal plant. There are more than 360 different species of Aloe. Its products have been used in health foods for medical and preservative purposes. The objective of this study was to search the effects of Aloe barbadensis on the rat's placenta. Gel form of Aloe barbadensis is used in the study. It is commercial, preserved but otherwise untreated form of Aloe Barbadensis gel capsul. Female Wistar Albino rats were divided into three groups. Placenta specimens from each groups were processed for the microscopic examination. Trophoblastic giant cells and spongiotrophoblasts were decreased in number after Aloe barbadensis; trophoblastic giant cells which showed degenerative changes. The nuclei of these giant cells were going degeneration characterized by pyknosis and bizarrely shaped. Extracellular matrix production around the cells was increased, thicker and more irregular basal membrane like formation around the cells. Decreased and abnormal vessel formation in labyrinth area was clear and reduced functional capacity of the trophoblastic barier. The study shows that, in the presence of Aloe barbadensis, relevant alterations associated with a possible compensatory adjustment to maintain adequate metabolic exchange take place in the structure of placenta. Our results also demonstrated that the exposure to Aloe barbadensis during pregnancy not led to fetal growth retardation, fetal death, abortion or teratogenic effect.

KEY WORDS: Aloe barbadensis; Effect; Placenta; Microscopic examination.

\section{INTRODUCTION}

Aloe vera is a perennial plant belonging to the family of Liliacea, which includes about 360 species and one of the few the medical plants that has maintained its popularity for long period of time (Rajasekaran et al., 2005). Aloe vera products have long been used in health foods for medical and preservative purposes from community and officinal medicine for an array of ailments (Hu et al., 2003).

Its gel form is mostly preferred traditionally (Paulsen et al., 2005). Its chemical and therapeutic spesifications are in review in recent times (Coats \& Ahola, 1979). Anthraquinin has to be removed from plant at the stage of usage (Vinson et al., 2005). There are different species of aloes grown in the dry regions of North American, Europe, and Asia. Aloe barbadensis is the most widely used both commercially and for its therapeutic properties (Hu et al.).

Polysaccharide containing plants which Aloe barbadensis is also among are used in various diseases as anti-inflammatory, antiulcer, antineoplastic and in wound healing and against hepatitis (Kim et al., 1999). It is known that it is activating macrophages and has also antiviral effect (Zhang \& Tizard, 1996.).

In some studies it is shown that Aloe has an antioxidative effect. Its antigenetoxic and chemopreventive effects are also proven ( $\mathrm{Hu}$ et al.). It is not published any study concerning the effect of Aloe barbadensis to placenta. However, there is a few studies related to effects of the other species to reproductive system. It is known that Aloe vera's aqueous extracts are used in women having infertility and dismenorrhea at western areas of Cameroon (Kim \& Lee, 1997; Telefo et al., 2002). In the same study, it is determined that some species of Aloe vera (Aloe buettneri, Dicliptera verticillata, Hibiscus macranthus and Justicia insularis) are increasing ovarian and uterus weight and also raising serum and ovarian estradiol levels (Telefo et al., 1998). In another study it is expressed that Aloe vera's

\footnotetext{
* Abant I'zzet Baysal University, Faculty of Medicine, Department of Anatomy. Bolu, Turkey.
}

*** Karaelmas University, Faculty of Medicine, Histology-Embriology. Zonguldak, Turkey. 
aqueous extracts might contain estrogen content. It is reported that Aloe vera extracts increase ovarian steroidogenesis and significantly increase production of estradiol end progesterone (Telefo et al., 2004). It is reported that Aloe vera extracts are not fetotoxic and have no abortus effect (Parry \& Matambo, 1992). It is proven that Aloe vera gel and extracts increase angiogenesis in chorioallantaoic membrane in chick embryos (Moon et al., 1999).

The objective of this study was to search the effects of Aloe barbadensis on the rat's placenta.

\section{MATERIAL AND METHOD}

After taking permission from Ethic Board of Experimental Animals normal adult (60-65 days old) Wistar Albino, female rats having no birth previously, are taken under care in an animal laboratory having conditions of $28 \pm 2{ }^{\circ} \mathrm{C}$ temperature, daily cycle of 12 hours light/dark, humidity ratio as $40 \%$. Body weights of female rats are between $150 \mathrm{~g}$ and $200 \mathrm{~g}$ (175.76 \pm 12.93$)$. Female rats are divided into three groups. Rats are leaved for coupling for three days as one male to two females. Aloe barbadensis is given in a daily dose of $25 \mathrm{mg} /$ $\mathrm{kg}(140 \mathrm{mg} / \mathrm{kg})$ group I with gavages starting from fourth day. Aloe barbadensis was in capsules containing $500 \mathrm{mg}$ soybean oil. 500 $\mathrm{mg}$ soybean oil is given to rats in group II with gavages. III group rats were control group. All of the three groups are fed with normal feed and water. Six rats are taken from each group at 21 day and deeply anaesthetized with sodium thiopenthal and then abdomen is opened with perfusion of $10 \%$ formaldehyde. Placentas are immediately ejected and put into a solution containing $10 \%$ formaldehyde. Rat's reproductive system organs and the other organs are also preserved in the same solution for further examination. Placentas belonging to all groups are weighed after cleaning under dissection microscope. Then, with making tissue follows they are stained in order to examine histologically.

Light Microscopic Examination. Placentas of each animal were cut in two equal parts.
These specimens were fixed with $10 \%$ buffered formalin, processed for microscopic examination and embedded in paraffin. Sections at $5 \mu \mathrm{m}$ thickness were cut from the paraffin blocks of each animal. The sections were deparaffinized and stained with Hematoxylene \& Eosin. All sections had a transversal view of the medial region of placenta. At least six sections from each placenta were examined and photographed under Olympus BX51 light microscope. Pictures were taken from each specimen at magnification of X10, X20, X40, X100. The histologic features of each placenta were also described as mild, moderate or severe in Table II.

Table I. Female rat's body and placenta weights.

\begin{tabular}{lccc}
\hline Groups & $\begin{array}{c}\text { First weight } \\
\text { mean }(\mathbf{g})\end{array}$ & $\begin{array}{c}\text { Final weight } \\
\text { mean }(\mathbf{g})\end{array}$ & $\begin{array}{c}\text { Placenta weight } \\
\text { mean }(\mathbf{g})\end{array}$ \\
\hline Group I(n=6) & $177.51 \pm 18.7$ & $218.14 \pm 13.25$ & $0.67 \pm 0.18$ \\
Group II(n=6) & $175.06 \pm 4.92$ & $237.58 \pm 11.94$ & $0.49 \pm 0.36$ \\
Group III(n=6) & $182.11 \pm 5.88$ & $257.84 \pm 39.89$ & $0.53 \pm 0.56$ \\
\hline
\end{tabular}

Table II. Data of litters.

\begin{tabular}{lcccc}
\hline Groups & $\begin{array}{c}\text { Litter } \\
\text { number }\end{array}$ & $\begin{array}{c}\text { Litter } \\
\text { number } \\
\text { mean }\end{array}$ & $\begin{array}{c}\text { Ex } \\
\text { fetus }\end{array}$ & $\begin{array}{c}\text { Litter body } \\
\text { weight mean } \\
(\mathbf{g})\end{array}$ \\
\hline Group I $\quad(\mathbf{n = 6})$ & 33 & $5.5 \pm 1.2$ & - & $6.06 \pm 0.34$ \\
Group II $\quad(\mathbf{n = 6})$ & 46 & $7.6 \pm 2.33$ & 1 & $5.26 \pm 0.42$ \\
Group III $(\mathbf{n = 6})$ & 52 & $8.6 \pm 1.36$ & - & $5.76 \pm 0.44$ \\
\hline
\end{tabular}

\section{RESULTS}

In all of three groups rats are weighed while starting the experiment. After, by weighing antenatally, their weight gain ratios are evaluated. In the result of statistical analysis done by using single sided variance analysis and Bonferroni tests, it is seen that there is a significant difference between groups I and III. The least weight gain was occurred in the group that is given Aloe barbadensis (Table I).

When the placental weights are evaluated, the means were determined as $0.67 \pm 0.18 \mathrm{~g}$ in group I, $0.49 \pm 0.36 \mathrm{~g}$ in group II and $0.53 \pm 0.56 \mathrm{~g}$ in group III. In the result of statistical analysis, it is determined significant difference between group I and II, groups I and III. Placental weight was higher in the group taking Aloe barbadensis (Table I). Body weights and numbers of litters were as shown in the Table II.

When fetus weights are compared statistically, it is determined significant difference between groups I and II and between groups II and III $(\mathrm{p}<0.05)$. The fetus that belongs to group II had the lowest weight.

Although, fetuses taking Aloe barbadensis are having the maximal weights, the difference from the normal group was not significant. 

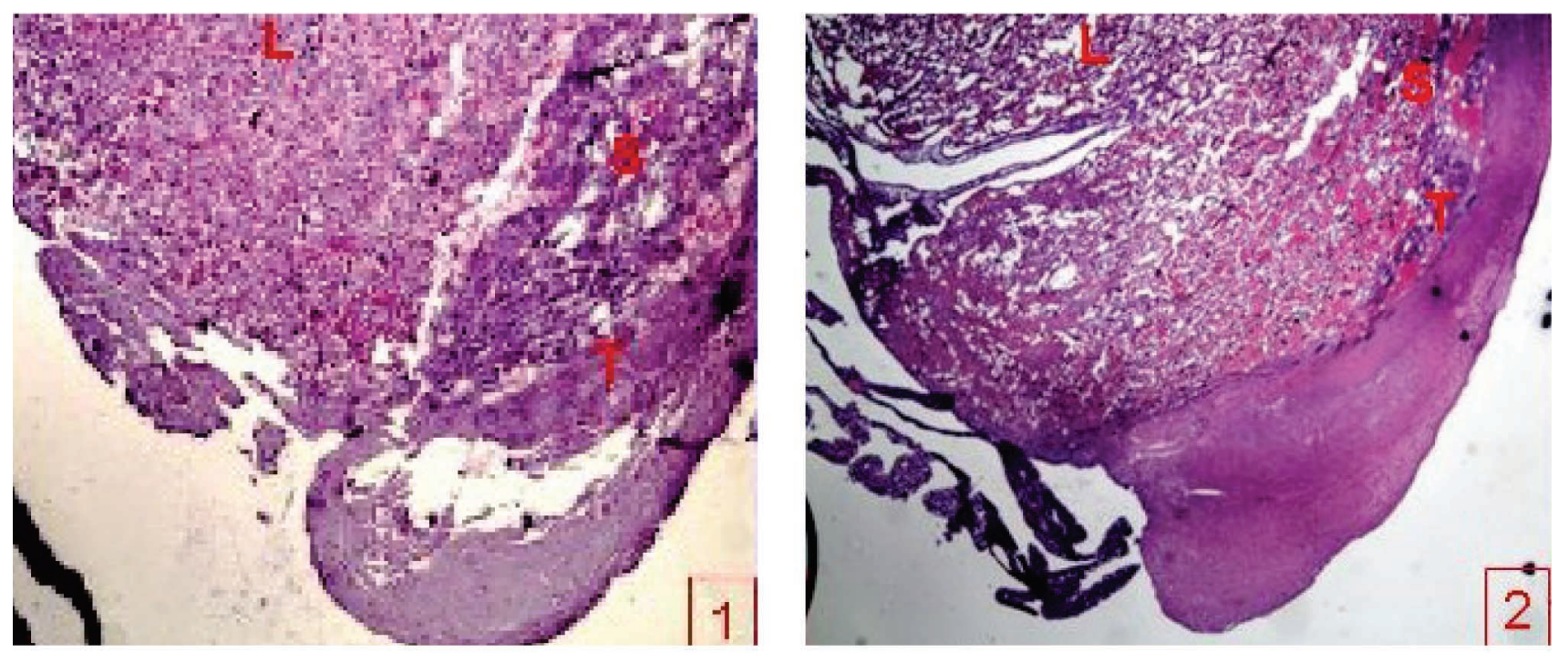

Figs. 1 and 2. Placentas of control (Fig. 1) and experimental group (Fig. 2). The area of trophoblastic cells and spongiotrophoblasts occupied has been decreased after application of Aloe barbadensis. Labyrinth also looks different from control. L: Labyrinth, S: Spongiotrophoblasts, T: Trophoblasts (X10, X10; H \& E).
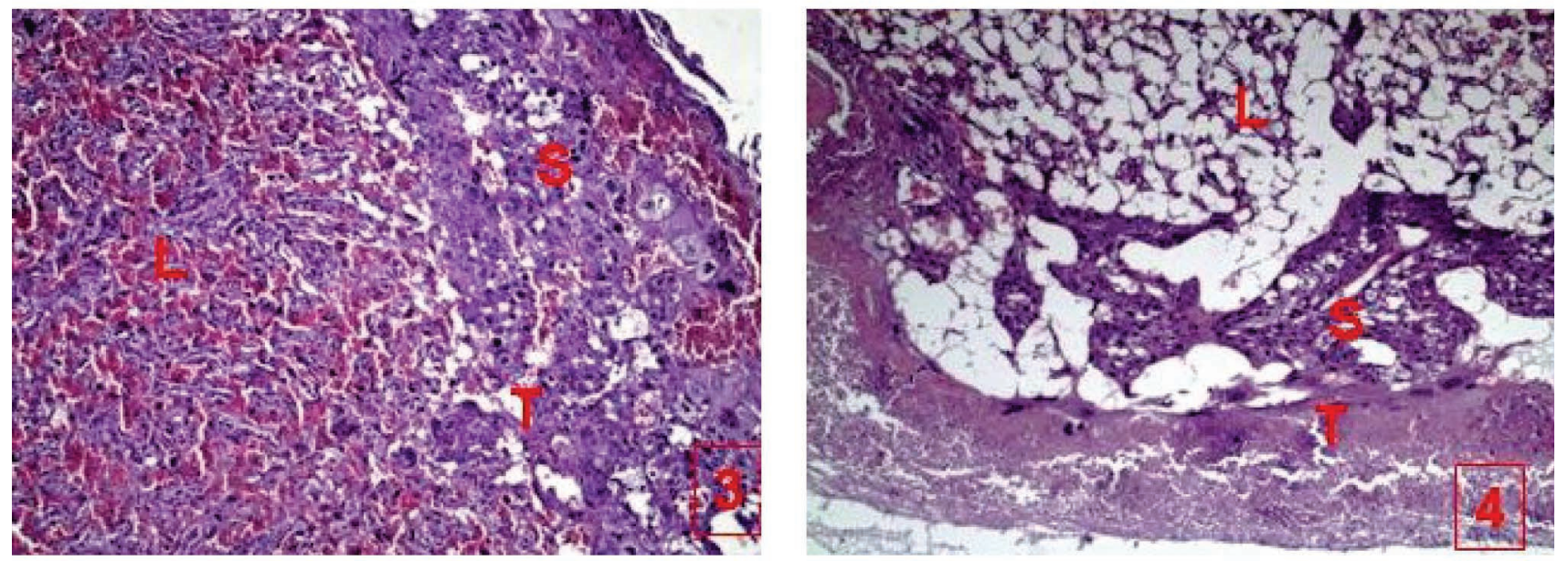

Figs. 3 and 4. Shows the placenta of a rat from control group while (Fig. 3). Fig. 4 is a section of a treated rat placenta. Please note that trophoblastic cells and spongiotrophoblasts were decreased in number. Histological changes in the labyrinth area is evident after the tratment. L: Labyrinth, S: Spongiotrophoblast, T: Trophoblastic Giant Cells. (X20, X20; H \& E).

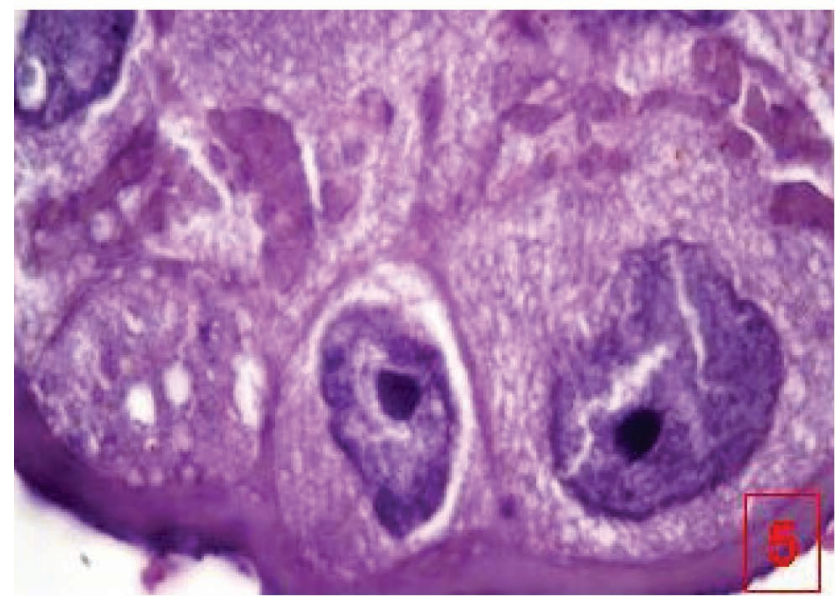

Fig. 5. Trophoblastic giant cells from the placenta of a control rat. Nucleoli of cells are seen in control group while nuclei of spongiotrophoblasts seems pyknotic and irregular in Aloe barbadensis treated group (X100, H \& E).

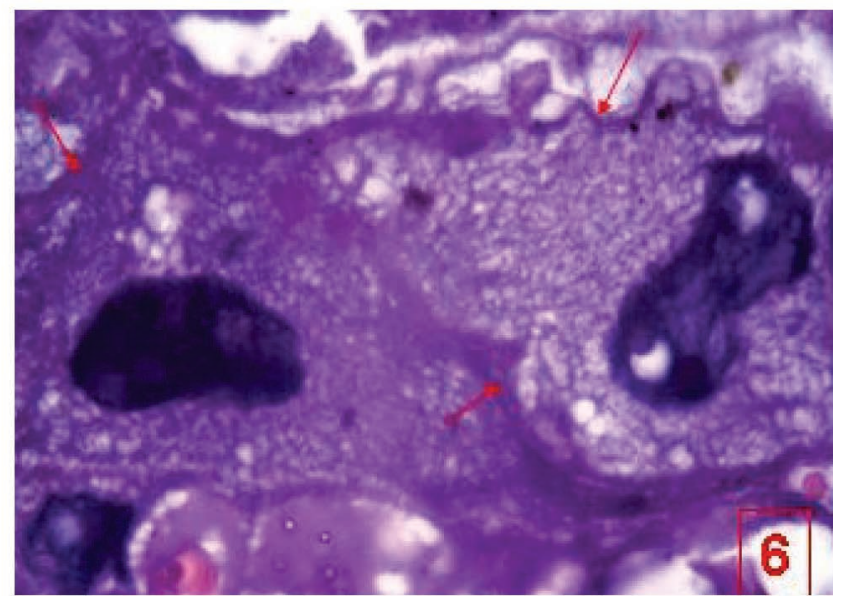

Fig. 6. Rat treated with Aloe barbadensis. Cytoplasms of the cells contain more and bigger vauoles in experimental group. Plasma membranes of the cells are also irregular. Basal membrane like formation around the cells(arrows) is more clear after the treatment. (X100; H \& E). 

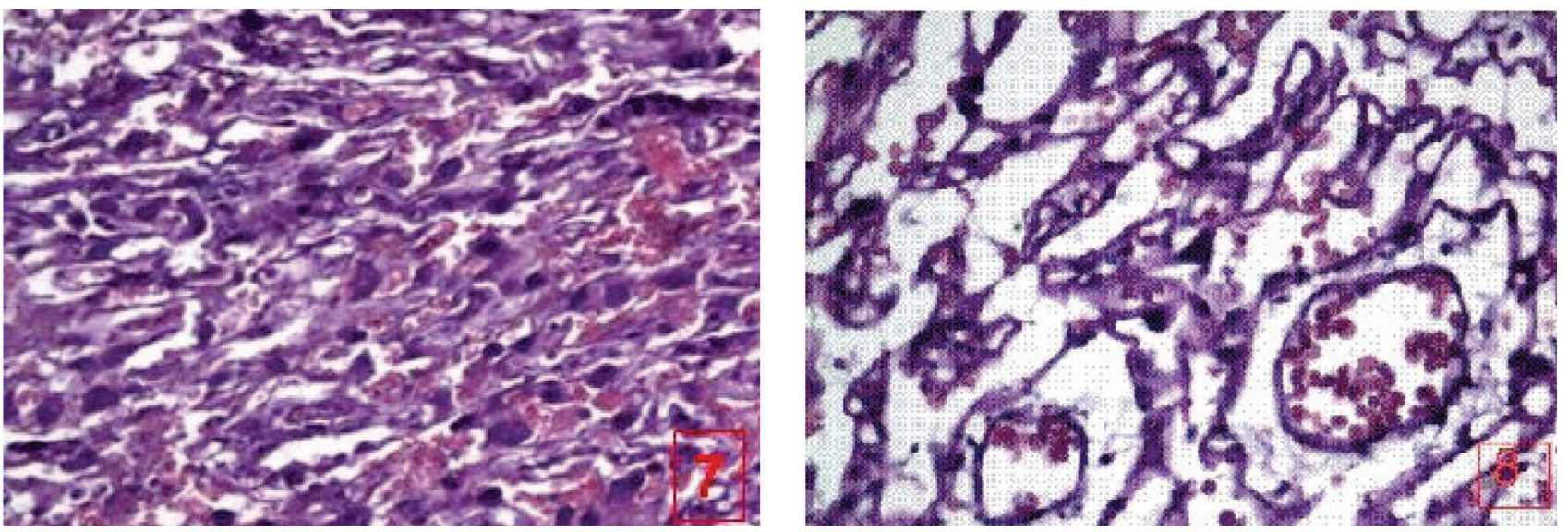

Figs. 7 and 8: Pictures show labyrinth area in control (Fig. 7) and aloe vera treated (Fig. 8) groups. Decreased and irregular vessel formation were seen after treatment. (X40, X40; H \& E).
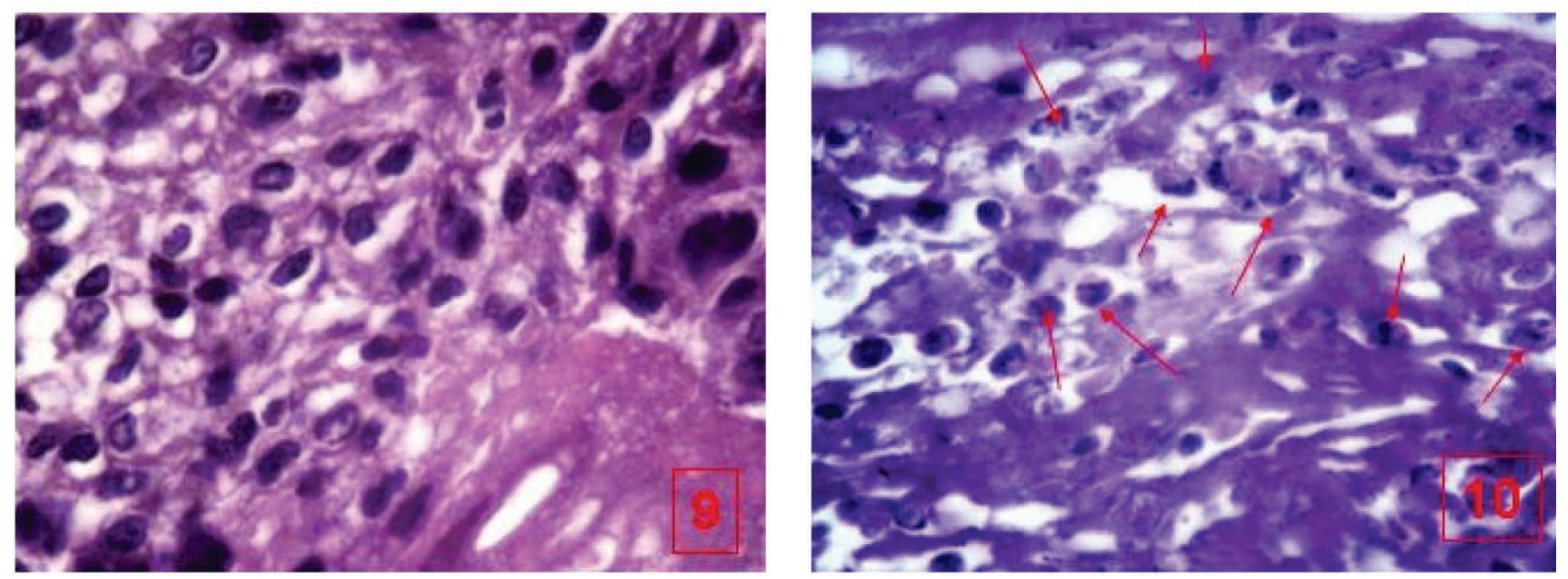

Figs. 9 and 10. Light microscopic pictures of decidual cells in control (Fig. 9) and Aloe barbadensis treated group (Fig. 10). Significant apopitotic changes of decidual cells are evident in Fig. 10. Please note the fragmentation of nuclei (arrows) (X40, X40, H \& E).
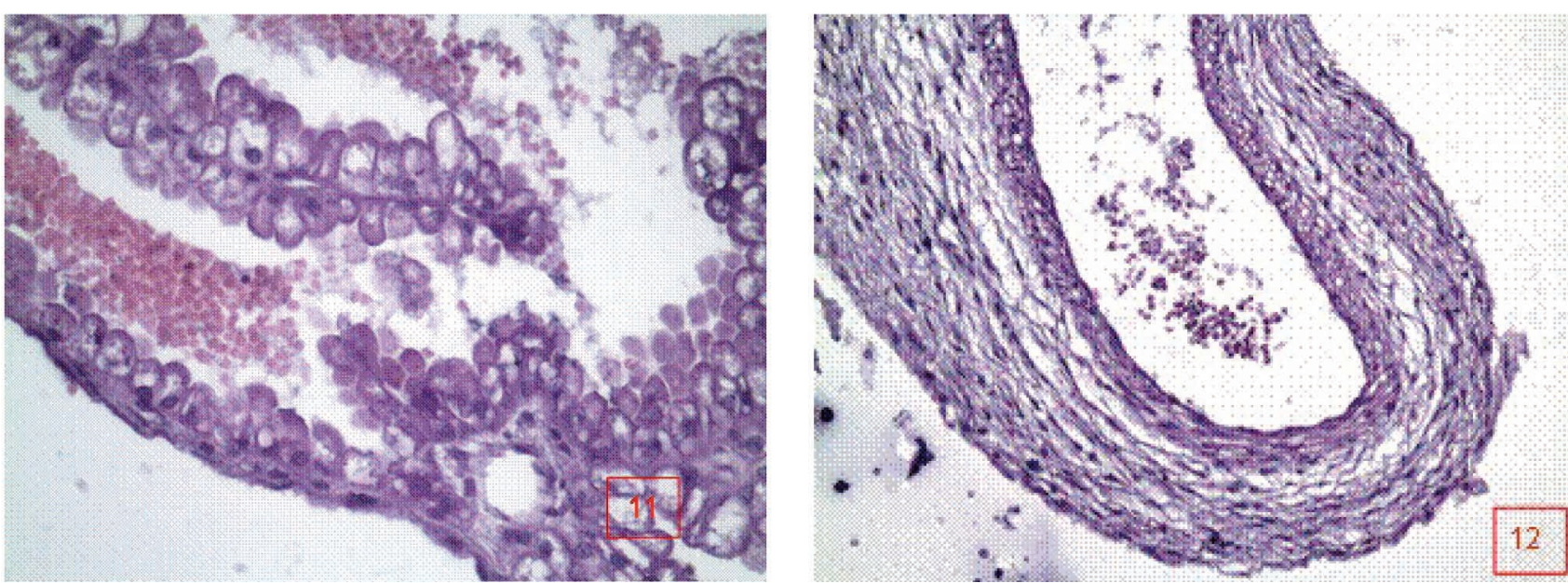

Figs. 11 and 12. They were taken from aloe vera received animals. Vitelline membrane (Fig. 11) and umbilical cord (Fig. 12) demonstrates normal histologic features (X40, X20; H \& E). 
Results of Histologic Examination. It wasn't found any outstanding difference in histological findings between groups II and III.

The ratio between the labyrinth area and the area occupied by spongiotrophoblasts was approximately $6: 1$ without any treatment (Fig. 1). There was no significant difference at this ratio in most rats in group I (Fig. 2). However; the administration of Aloe barbadensis altered spongiotrophoblastic area at some degree in placentas of all group I animals (Figs. 2, 4 and 6). Trophoblastic giant cells and trophoblasts showed normal morphologic features at light microscope level in group I and II (Figs. 1, 3 and 5) while all sections from different animals in group I demonstrated the following histological findings: Trophoblastic giant cells and spongiotrophoblasts were decreased in number after administration of Aloe barbadensis (Figs. 2 and 3). This did not change the proportion which was mentioned earlier. In the spongiotrophoblast area; undifferentiated cells were predominated in group I and II. After the administration of Aloe barbadensis; trophoblastic giant cells, which showed degenerative changes were common (Figs. 4 and 6). The nuclei of these giant cells in groups I and II were demonstrated typical histologic features. Some of the trophoblastic giant cells revealed many heterogenous cytoplasmic vacuoles, presumably phagosomes; while others were going degeneration characterized by pyknosis and bizarrely shaped nuclei in Aloe barbadensis exposed group (Fig. 6). Nucleoli of these cells were seen clearly in control group while they were mostly invisible after the administration (Figs. 5 and 6). Cytoplasms of the most cells contained more and bigger vacuoles in group I. Extracellular matrix production around the cells was increased after the administration of Aloe barbadensis and this caused thicker and more irregular basal membrane like formation around the cells (Figs. 5 and 6). In the labyrinth area; decreased and irregular vessel formation in the labyrinth region was clear (Figs. 7 and 8).

In the maternal-fetal interphase; decidual cells showing apopitotic changes were common after the application of Aloe barbadensis (Figs. 9 and 10). Decidual cells exhibited nuclei with bizarre shapes. Most of decidual cells were fragmented after the application of Aloe barbadensis (Fig. 10).

Cells located at deeper regions showed healthy features, compact organization, regular size and normal nuclear morphology. Vitelline membrane and umbilical cord did not show any major histological change after the administration of Aloe barbadensis (Figs. 11 and 12). All changes were evaluated as mild, moderate and severe and then they were summarized in Table III.

\section{DISCUSSION}

Parry \& Matambo applied that crude extracts of three species of aloes (A. globuligemma, A.chabaudii, A. cryptopoda) on rats and mice. The most toxic was $A$. globuligemma, toxic effects in rats were CNS depression, and post mortem investigations showed widespread haemorrhagic lesions. Rats which survived the treatment delivered normal sized, healthy litters at term. The aloe species don't posse abortifacient activity at doses which are not toxic to the animals.

Table III. Groups and histological changes.

\begin{tabular}{llcc}
\hline & Parameter & Groups II and III & Group I \\
\hline Maternal-Fetal interface & Vascular congestion & + & + \\
& Infiltrate of leuococytes & - & - \\
& Apopitotic changes in desidua & - & +++ \\
Trophoblast giant cells & Phagocytotic vacuoles & - & ++ \\
& Cell number & - & + \\
& Cell volume & - & ++ \\
& Degeneration & - & ++ \\
& Atypical shape & - & ++ \\
Trophopspongium & Nuclear polymorphism & - & - \\
& Glycogen cells & - & - \\
Labyrinth & Undifferentiated cells & - & ++ \\
& Cell number & - & ++ \\
Vitelline membrane & Vascular congestion & + & ++ \\
Umbilical cord & Decreased and irregular vessel & - & - \\
\hline
\end{tabular}

No changes: -; Mild changes: +, Moderate changes: ++; Severe changes: +++ 
Moon et al. demonstrate that Aloe vera gel and its extracts are angiogenic on the chorioallantoic membrane of chick embryo. The final fraction of Aloe vera gel, bsitosterol showed a potent angiogenic activity in the chorioallantoic membrane.

In the presence of heparin, b-sitosterol stimulated motility of human umbilical vein endothelial cells.

Our study showed that Aloe barbadensis exposure cause decrease in number in trophoblasts and trophoblastic giant cells. Trophoblastic giant cells have been reported as precursor cells of more differentiated trophoblasts. The number of phagosomic vacuoles per cell was visibly higher in the rat placentas exposed to Aloe barbadensis. It is possible that Aloe barbadensis might cause cells of maternal-fetal interface (decidual cels and spongiotrophoblasts) to degenerate and die; thus stimulating trophoblasts to phagocytose and remove damaged cells. Phagocytosis acts as a biological mechanism for elimination of dead or degenerating cells. It seems likely that degeneration and finally decline of giant cells finally causes diminishment of trophoblasts.

Decreased and abnormal vessel formation in labyrinth area was also clear. This might be caused by reduced functional capacity of the trophoblastic barier because of Aloe barbadensis exposure.

Severe apopitotic changes of decidual cells were also observed in group I. Davies \& Glasser (1968) have reported these changes as characteristics in the final days of gestation. However; the significant difference between control and experimental group led us to think that Aloe barbadensis caused additional apopitotic effects on decidual cells.

In conclusion, the study shows that, in the presence of Aloe barbadensis, relevant alterations associated with a possible compensatory adjustment to maintain adequate metabolic exchange take place in the structure of placenta. Consequently, taken together, these alterations may decrease the functional role of placenta and contribute with adverse reproductive outcomes. Our results also demonstrated that the exposure to Aloe barbadensis during pregnancy not led to fetal growth retardation or fetal death. The results show that the dosages of Aloe Barbadensis higher than $25 \mathrm{mg} / \mathrm{kg}$ is more hazardous for placenta. With this dosage no abortion, fetal death, fetal growth retardation and teratogenic effect was occured but it caused large placenta and large fetus.

KOSIF, R.; AKTA, G. \& ÖZTEKIN, A. Examen microscópico de la placenta de ratas prenatalmente expuestas a Aloe barbadensis. Estudio preliminar. Int. J. Morphol., 26(2):275-281, 2008.

RESUMEN: Aloe barbadensis es ampliamente utilizada comercialmente, debido a sus propiedades terapéuticas. Desde la antigüedad, se ha utilizado como planta medicinal para combatir una variedad de enfermedades. Hay más de 360 especies diferentes de Aloe. Sus productos han sido utilizados en los alimentos saludables para propósitos medicos y preventivos. El objetivo de este estudio fue buscar los efectos del Aloe barbadensis en la placenta de la rata. Se utilizó gel de Aloe barbadensis en el estudio. Su presentación comercial, cápsulas de gel de Aloe barbadensis de uso preventivo, no de tratamiento. Ratas Wistar albinas hembras se dividieron en tres grupos. Las placentas de cada uno de los especímenes de los grupos fueron procesadas para el examen microscópico. Las células gigantes trofoblásticas y los espongioblastos disminuyeron de número después de ser expuestas a Aloe barbadensis; las células trofoblásticas gigantes mostraron cambios degenerativos. Los núcleos de estas células gigantes se caracterizaron por la degeneración, mostrando picnosis y forma extraña. La producción de matriz extracelular alrededor de las células se incrementó, hubo engrosamiento y formación de una membrana basal más irregular alrededor de las células. La disminución y formación de vasos anormales en la zona del laberinto eran evidentes y además hubo reducción de la capacidad funcional de la barrera trofoblástica. El estudio mostró que, en presencia de Aloe barbadensis, las alteraciones asociadas con un posible ajuste compensatorio para mantener un nivel adecuado de intercambio metabólico, tienen lugar en la estructura de la placenta. Nuestros resultados también demostraron que la exposición al Aloe barbadensis durante el embarazo no produjo retraso del crecimiento fetal, muerte fetal, aborto ni efecto teratogénico.

PALABRAS CLAVE: Aloe Barbadensis; Placenta; Examen microscópico.

\section{REFERENCES}

Coats, B. C. \& Ahola, R. Aloe vera the silent healer. In: Coats, B. C. (ed.). A Modern Study of Aloe vera. Garland, Dallas, 1979.
Davies, J. \& Glasser, S. R. Histological and fine structural observations on the placenta of the rat. Acta Anat. (Basel), 69(4):542-608, 1968. 
Hu, Y.; Xu, J. \& Hu, Q. Evaluation of antioxidant potential of aloe vera (Aloe barbadensis Miller) extracts. J. Agric. Food Chem., 51(26):7788 -91, 2003.

Kim, H. S.; Kacew, S. \& Lee, B. M. In vitro chemopreventive effects of plant polysaccharides (Aloe barbadensis Miller, Lentinus edodes, Ganoderma lucidum and Coriolus versicolor). Carcinogenesis, 20(8):1637-40, 1999.

Kim, H. S. \& Lee, B. M. Inhibition of benzo(a)pyrene-DNA adduct formation by Aloe barbadensis Miller. Carcinogenesis, 18(4):771-6, 1997.

Moon, E. J.; Lee, Y. M.; Lee, O. H.; Lee, M. J.; Lee, S. K.; Chung, M. H.; Park, Y. I.; Sung, C. K.; Choi, J. S. \& Kim, K. W. A novel angiogenic factor derived from Aloe vera gel: beta-sitosterol, a plant sterol. Angiogenesis, 3(2):117-23, 1999.

Parry, O. \& Matambo, C. Some pharmacological actions of the aloe extracts and Cassia abbreviata on rats and mice. Cent. Afr. J. Med., 38(10):409-14, 1992.

Paulsen, E.; Korsholm, L. \& Brandrup, F. A double-blind, placebo-controlled study of a commercial Aloe vera gel in the treatment of slight to moderate psoriasis vulgaris. J. Eur. Acad. Dermatol. Venereol., 19(3):326-31, 2005.

Rajasekaran, S.; Sivagnanam, K. \& Subramanian, S. Antioxidant effect of Aloe vera gel extract in streptozotocin-induced diabetes in rats. Pharmacol. Rep., 57(1):90-6, 2005.

Telefo, P. B.; Moundipa, P. F.; Tchana, A. N.; Tchouanguep Dzickotze, C. \& Mbiapo, F. T. Effects of an aqueous extract of Aloe buettneri, Justicia insularis, Hibiscus macranthus, Dicliptera verticillata on some physiological and biochemical parameters of reproduction in immature female rats. $J$. Ethnopharmacol., 63(3):193-200, 1998.

Telefo, P. B.; Moundipa, P. F. \& Tchouanguep, F. M. Inductive effect of the leaf mixture extract of Aloe buettneri, Justicia insularis, Dicliptera verticillata and Hibiscus macranthus on in vitro production of estradiol. J. Ethnopharmacol., 91(2-3):225-30, 2004.

Telefo, P. B.; Moundipa, P. F. \& Tchouanguep, F. M. Oestrogenicity and effect on hepatic metabolism of the aqueous extract of the leaf mixture of Aloe buettneri, Dicliptera verticillata, Hibiscus macranthus and Justicia insularis. Fitoterapia, 73(6):472-8, 2002.
Vinson, J. A.; Al Kharrat, H. \& Andreoli, L. Effect of Aloe vera preparations on the human bioavailability of vitamins C and E. Phytomedicine, 12(10):760-5, 2005.

Zhang, L. \& Tizard, I. R. Activation of a mouse macrophage cell line by acemannan: the major carbohydrate fraction from Aloe vera gel. Immunopharmacology, 35(2):11928, 1996.

Correspondence to:

Rengin Kosif, Assistant Prof.

Abant I'zzet Baysal University

Faculty of Medicine

Department of Anatomy

Bolu - TURKEY

Tel: (0374) 2534656-3043

Fax: (0374) 2534559

Email: rengink@yahoo.com

Received: 25-01-2008

Accepted: 16-04-2008 
